\section{Hawk Attack}

On 2 August 1992 I had a rather mystifying experience with a Swainson's Hawk.

I had gone to Last Mountain Lake bird refuge to spend the day explcring the area. It was a warm, sunny day with a pleasant breeze. It was about noon when I parked my vehicle on one of the grid roads. I chose to walk along a path which led through an expanse of grasses and flowers to a thicket about 75 yards away; beyond that, about another 100 yards, there was another thicket. I walked quite slowly, and although I noticed two Swainson's Hawks far overhead, nothing unusual happened until I was about two-thirds of the distance to the second thicket.

I walked through a spider's web, and paused to brush the spider off my leg. I stooped to do this, and while I was looking down at my leg, I heard a tremendous whooshing sound. I lifted my eyes from my leg to get a phenomenal view of the talons and underside of a hawk. Reflexively I dropped to a crouch, and the bird pulled up and away. I had no idea what had prompted its behaviour. I moved on about 10 or 15 feet and looked at the second thicket through my binoculars. I wondered if the bird had been trying to discourage me from coming closer to its nest, though it seemed late in the year for that and I could see nothing of significance in the thicket.

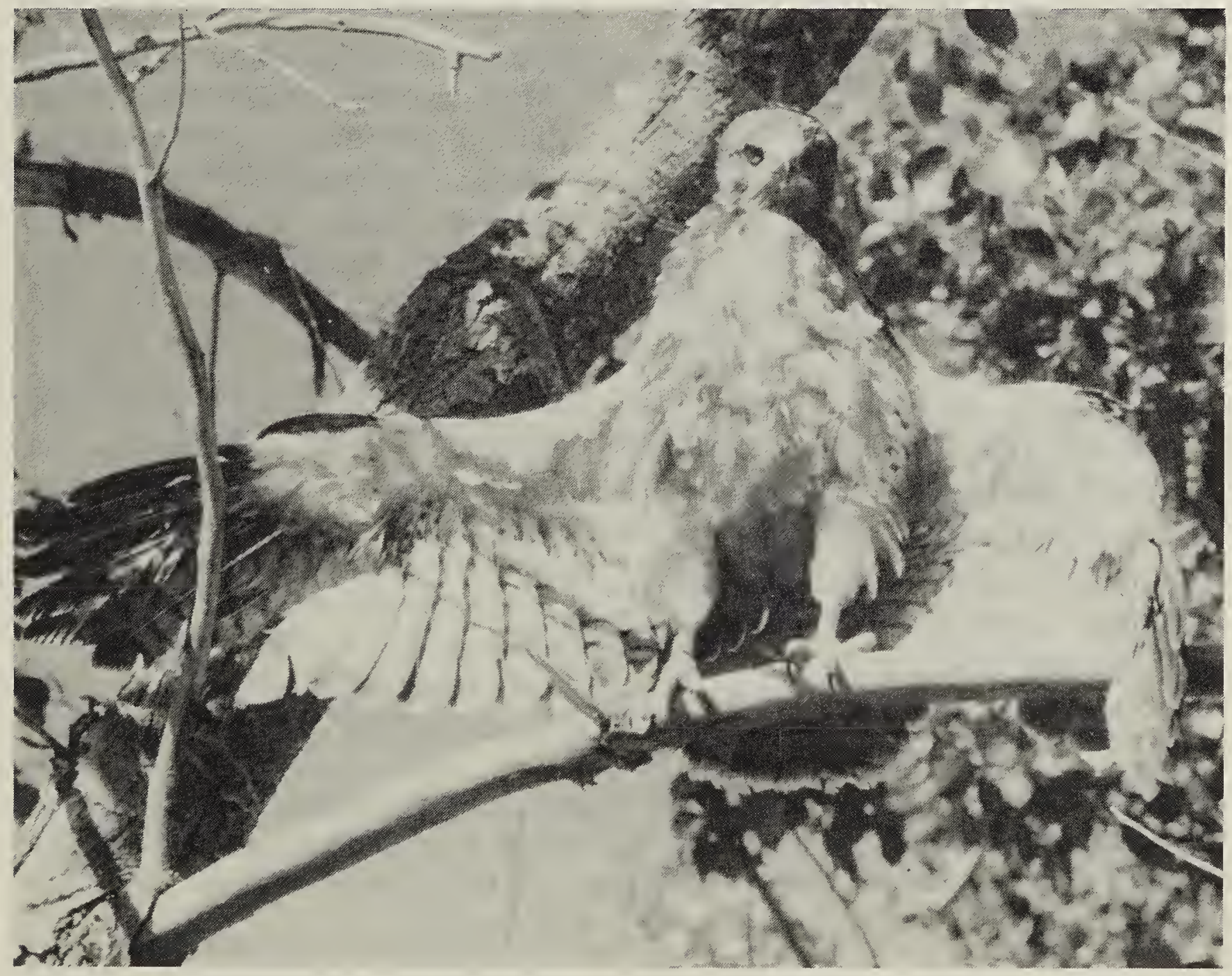

Young Swainson's Hawk

C. Anweiler 
Nevertheless, I was a little unnerved and decided to retreat.

I was probably at about the same spot where the bird had first dived at me when I heard that whoosh of wind through feathers again, and was hit a blow to the back of my head. I sped up, not wanting to turn around or look up for fear of getting those talons in the face. Within minutes I heard the whoosh again. This time I ducked. The bird's talons pulled off my hat and punctured my scalp in a few places. Retrieving my hat (a nondescript grey ball cap) from where it had fallen, I spun around waving it and yelling, to see one hawk winging over the grasses - I am not sure where the other one was. I continued my speedy retreat, but nothing further happened, and, when I left, both hawks were high overhead.

I am quite mystified by this experience. What could have prompted the hawks' behaviour? A friend suggested that a young hawk might have been in the grasses nearby. Would this be at all likely? I also wonder if my hat waving scared the hawk away, or whether it had simply accomplished its purpose by then. I rather suspect the latter, but I welcome others' opinions. Finally, if something similar happens again (hopefully it will not), what is the best way to react?

Jeremy Baumbach, 504-2339 Lorne Street, Regina, Saskatchewan. S4P 2N2

\section{ALBINO GRAY SQUIRREL IN OHIO}

Last fall I attended a meeting in Columbus, Ohio. During a noon hour break (on 11 November 1991), I went for a walk along the nearby Olentangy River, where there was a sizeable stand of what appeared to be old growth deciduous forest.

I watched the busy activity of many Gray Squirrels as they went about their business putting up rations for the winter. At one point, I spied a squirrel-sized animal behind some dense hedges. It was as white as snow. I crept within about 29 feet and was able to clearly identify the animal as an all-white adult Gray Squirrel, in the company of two other squirrels. Unfortunately, at that point, a stroller accompanied by a large dog came down the path and the colourless squirrel made itself scarce.

Ken Pivnick, 209 7th Street East, Saskatoon, Saskatchewan. S7H oW9

At a "game ranch" in Oklahoma, you could shoot a "male African lion with a good mane" for $\$ 5,995$. At another in California, one customer paid $\$ 10,500$ to kill a leopard, a cougar and a Bengal tiger. In Texas there are just under 500 "game ranches." Ted Williams, Audubon Jan-Feb/92 